\title{
Qaul Shahabi dan Aplikasinya dalam Fiqh Kontemporer
}

\author{
Muchamad Coirun Nizar* \\ Universitas Islam Sultan Agung (UNISSULA), Semarang \\ Email : choirun.nizar@unissula.ac.id
}

\begin{abstract}
The dynamics of the development of Islamic law can not be separated from the disciplines of ushul fiqh which has a number of methodologies as the theorem and the foundation for berijtihad. Qaul Sh ahabi became one of the theorems used by the Fiqh Ulama in overcoming the problems that occur among Muslims. Qaul shahabi is about one shahabah expressed an opinion then spread among other shahabah, without knowing any shahabat who opposed. Qaul Shahabi came into existence as one of the references of Islamic law since the time of Tabi'in. The dignity of qaul shahabi is disputed by Ulama. Imam Malik, Ar Razi, Hanafiyyah, Asy Syafi'i with Qaul Qadim and Ahmad bin Hanbal received Qaul Shahabi as hujjah. Asya Shafiyah, Mu'tazila, Asy Shafi with Qaul Jadid, Shi'ah, Al Karkhi, Contemporary Scholar of Maliki and Hanafi and Ibn Hazm reject Qaul Shahabi as hujjah. Similar to other hujjah, Qaul Shahabi can also be a reference to contemporary issues. The difference of opinion of Ulama about the use of Qaul Shahabi as hujjah affect its application in contemporary fiqh.
\end{abstract}

Keywords: Qaul Shahabi, Aplication, Contemporary Fiqh.

\section{Abstrak}

Dinamika perkembangan hukum Islam tidak dapat terlepas dari disiplin ilmu ushul fiqh yang memiliki sejumlah metodologi sebagai dalil serta landasan untuk berijtihad. Qaul Shahabi menjadi salah satu dari dalil yang digunakan oleh Ulama Fiqh dalam mengatasi problematika yang terjadi di

* Dosen Program Studi Ahwal Syakhshiyah, Jurusan Syariah, Fakultas Agama Islam, UNISSULA; Kandidat Doktor Islamic Studies, Program Beasiswa 5000 Doktor Kemenag di UIN Walisongo Semarang. 
kalangan umat Islam. Qaul shahabi ialah perihal satu orang shahabah mengemukakan sebuah pendapat kemudian menyebar di kalangan shahabah lainnya, tanpa diketahui seorang shahabat pun yang menentang. Qaul Shahabi menjadi eksis sebagai salah satu rujukan hukum Islam sejak masa Tabi'in. Kehujjahan qaul shahabi diperselisihkan oleh kalangan Ulama. Imam Malik, Ar Razi, Hanafiyyah, Asy Syafi'i dengan Qaul Qadim beliau dan Ahmad bin Hanbal menerima Qaul Shahabi sebagai hujjah. Sedangkan Ulama Asya'irah, Mu'tazilah, Asy Syafi'i dengan Qaul Jadid beliau, Ulama' Syi'ah, Al Karkhi, Ulama Kontemporer Madzhab Maliki dan Hanafi serta Ibnu Hazm menolak Qaul Shahabi sebagai hujjah. Sama halnya dengan hujjah lain, Qaul Shahabi juga dapat menjadi rujukan bagi permasalahan kontemporer. Perbedaan pendapat Ulama tentang penggunaan Qaul Shahabi sebagai hujjah berpengaruh pada aplikasinya dalam fiqh kontemporer.

Kata Kunci: Qaul Shahabi, Aplikasi, Fiqh Kontemporer.

\section{Pendahuluan}

$12 \begin{aligned} & \text { ata 'Shahabat' dalam kajian keislaman merupakan } \\ & \text { sebutan bagi orang-orang yang hidup menyertai Nabi } \\ & \text { Muhammad dan beriman kepada Nabi. Dalam }\end{aligned}$ kehidupan Nabi di dunia ini selama 62 tahun lebih, telah banyak orang yang menyertai dan mendampingi perjuangan beliau baik ketika di Makkah maupun di Madinah. Jumlah mereka juga banyak dan silih berganti antar generasi. Di antara mereka ada yang tua dan ada juga yang masih berusia muda.

Para shahabat menyertai Nabi dalam segala hal, tidak hanya berperang saja. Mereka juga menjadi generasi penerus penyebaran agama Islam pasca meninggalnya Nabi. Para shahabat yang jumlahnya banyak itu, memiliki keanekaragaman kemampuan. Ada yang mahir dalam bidang peperangan seperti Khalid ibn Walid. Ada yang mahir dalam bidang penulisan seperti Zaid ibn Tsabit. Dan adapula yang menjadi penerus Nabi dalam hal menjadi sumber hukum pasca meninggalnya sumber hukum utama yakni Nabi Muhammad SAW. 
$22 \mid$ Muchamad Coirun Nizar

Tidak dapat dipungkiri bahwa sepeninggal Nabi Muhammad SAW, umat Islam tiada lagi rujukan untuk bertanya melainkan kepada para sahabat Nabi. Terlebih ketika muncul permasalahan-permasalahan baru yang belum pernah terjadi sebelumnya. Seiring dengan perkembangan situasi dan kondisi seperti itulah, kemudian banyak sahabat yang tampil memberikan pendapat (fatwa) dalam menjawab berbagai masalah hukum yang muncul. Sebagian ahli ushul fiqh menyebut pendapat sahabat dengan qaul sahabi (perkataan/ pendapat sahabat). Sebahagian lain menamakannya dengan fatwa sahabi.

Dalam perkembangannya, qaul shahabi menjadi eksis sebagai salah satu rujukan hukum Islam sejak masa Tabi'in. qaul shahabi kemudian menjadi salah satu hujjah yang diperselisihkan keabsahannya oleh para Ulama madzhab. Artikel ini hendak menyajikan informasi tentang qaul shahabi sebagai salah satu hujjah yang diperselisihkan Ulama serta tentang kehujjahan qaul shahabi dan aplikasinya dalam fiqh kontemporer.

\section{Qaul Shahabi dalam Teori dan Aplikasi}

Qaul Shahabi merupakan salah satu sumber hukum Islam dalam ilmu ushul fikh yang tidak disepakati kehujjahannya. Secara bahasa, Qaul shahabi terdiri dari dua kosa kata, qaul dan shahabi. Qaul dalam bahasa Arab berarti ucapan, perkataan dan pendapat. ${ }^{1}$ Atau jika dibawa ke persoalan istinbath, berarti kata yang terangkai dalam sebuah klausa yang terucapkan, atau makna imajiner yang tersusun dalam sebuah proposisi imajiner. ${ }^{2}$ Sedangkan shahabi berasal dari kata shuhbah yang berarti pertemanan dan persahabatan. ${ }^{3}$ Dalam terminologi ushul fikh, shahabah merupakan bentuk tunggal dari kata shahib, yang

${ }^{1}$ Ahmad Warson Munawwir, Kamus Al Munawwir, (Surabaya: Pustaka Progressif, 1997), 1172.

2 Jaenal Aripin, Kamus Ushul Fikh, (Jakarta: Kencana, 2012), 156.

${ }^{3}$ Ahmad Warson Munawwir, Kamus...., 762.

ulul albab: Jurnal Studi dan Penelitian Hukum Islam 
berarti sekelompok orang yang menemani Rasulullah SAW dari golongan Anshar dan Muhajirin dan generasi setelahnya yang mati dalam keadaan Islam. ${ }^{4}$

Perlu pendalaman serius untuk mengungkap makna shahabat sebelum memaknai secara utuh terhadap istilah qaul shahabi. Terdapat perbedaan Ulama dalam memaknai shahabat antara Ulama ahli hadis dengan ahli ushul. Shahabah dalam terminologi ushuliyyin berarti seseorang yang bertemu dengan Rasulullah SAW. Dalam keadaan beriman serta menemaninya dalam waktu yang lama. Sedangkan menurut ahli hadis, shahabah ialah seorang Muslim yang bertemu dengan Rasul dan meninggal dalam keadaan Muslim pula baik pertemuaannya sebentar maupun lama. ${ }^{5}$ Point penting dalam mendefinisikan shahabah antara lain; muslim/mukmin dan pernah hidup bersama Nabi atau paling tidak bertemu dengan Nabi. Sedangkan kata shahabi sendiri sebenarnya merupakan bentuk kata shahabah yang disisipi ya' nisbiy yang berfungsi sebagai penisbatan. Artinya, yang dinisbatkan pada shahabat Nabi.

Qaul shahabi dalam terminologi ushul fikh berarti perihal satu orang shahabah mengemukakan sebuah pendapat kemudian menyebar di kalangan shahabah lainnya, tanpa diketahui seorang shahabat pun yang menentang. ${ }^{6}$ Sebenarnya, terdapat istilah lain yang dapat dikatakan sama dengan qaul shahabi, yakni madzhab shahabi. Jika diartikan secara etimologi, madzhab berarti pendapat, teori, doktrin dan kepercayaan. ${ }^{7}$ Artinya, ada kesamaan antara istilah qaul shahabi dengan madzhab shahabi yaitu keduanya dapat berarti pendapat yang disandarkan kepada shahabat Nabi. Namun terdapat perbedaan istilah antara keduanya. Perbedaan keduanya terletak pada kuantitas sahabat yang berpendapat. Jika Qaul shahabi

${ }^{4}$ Jaenal Aripin, Kamus.... ., 381.

${ }^{5}$ Wahbah Az Zuhaili, Ushul al Fikh al Islami, (Beirut: Dar al Fikr, 1986), 850.

${ }^{6}$ Jaenal Aripin, Kamus..., 154.

${ }^{7}$ Ahmad Warson, Kamus... , 452. 
$24 \mid$ Muchamad Coirun Nizar

merupakan pendapat perorangan yang dimungkinkan berbeda antara satu sahabat dengan yang lain. Sedangkan madzhab shahabi merupakan pendapat kolektif sahabat. Dalam hal ini, madzhab shahabi juga dikenal dengan istilah ijma' shahabi. ${ }^{8}$

Sebagaimana layaknya suatu komunitas masyarakat, tidak semua sahabat ahli dalam hukum Islam. Bakat dan keahliannya pun berbeda-beda. Sebagian sahabat mendalami dan menekuni masalah-masalah hukum. Sehingga tidaklah mengherankan, jika sebagian sahabat populer dengan fatwafatwa hukumnya. ${ }^{9}$ Di antara beberapa shahabat yang populer namanya dalam bidang hukum Islam antara lain: Umar ibn Khattab, 'abdullah bin Mas'ud, Zaid bin Tsabit, Abdullah bin Umar bin Khattab, Aisyah, dan 'Ali bin Abi Thalib. Mereka ini adalah sahabat yang banyak berfatwa tentang hukum Islam. ${ }^{10}$

Ulama sepakat menjadikan Qaul shahabi sebagai hujjah dalam permasalahan yang non ijtihadi (bukan wilayah ijtihad) dan tidak membutuhkan peran ra'yu (logika). Ulama juga sepakat qaul shahabi yang telah menjadi Ijma' Shahabat baik sharih maupun sukuti seperti bagian waris seperenam bagi nenek. Ulama juga sepakat bahwa qaul shahabi yang merupakan hasil ijtihad perorangan tidak menjadi hujjah terhadap shahabat lain. Ikhtilaf terjadi ketika qaul shahabi menjadi hujjah bagi generasi Tabi' in dan sesudahnya. ${ }^{11}$

Menurut Tarhib Ad Dusiri, Qaul Shahabat yang masyhur dan bertepatan dengan pendapat para Shahabat lain maka menjadi Ijma' Shahabat. Qaul Shahabat yang masyhur namun bertentangan dengan pendapat para shahabat hanya dapat menjadi hujjah ketika dikuatkan oleh dalil lain. Qaul Shahabat yang tidak masyhur atau tidak diketahui kemasyhurannya

\footnotetext{
${ }^{8}$ Abd.Rahman Dahlan, Ushul Figh, (Jakarta: Amzah,2010), 225.

${ }^{9}$ Abd.Rahman Dahlan, Ushul.... , 225.

10 Satria Effendi,M.Zein, Ushul Fiqh,(Jakarta;Kencana,2009), 169.

${ }^{11}$ Wahbah Az Zuhaili, Ushul al Fikh... , 851.
}

ulul albab: Jurnal Studi dan Penelitian Hukum Islam 
Qaul Shahabi dan Aplikasinya ... $\mid 25$

inilah yang merupakan subtansi dari ikhtilaf Ulama' yang terjadi. $^{12}$

\section{Qaul Shahabi Sebagai Dalil Syara'}

Dalam sejarahnya, qaul shahabi atau madzhab shahabat muncul ketika umat Islam menjadikan para shahabat sebagai rujukan utama dalam mencari kepastian hukum Islam. Setidaknya ada dua faktor yang ikut melatar belakangi munculnya qaul shahabi antara lain Ekspansi wilayah Islam serta persoalan baru dan terbatasnya teks.

Sepeninggal Rasulullah, Islam melalui para shahabat menyebar ke beberapa daerah seperti Persia, Mesir, Irak dan Syiria. Kondisi ini tentunya membuka peluang terjadinya akulturasi dan asimilasi antara berbagai tradisi yang ada di daerah-daerah tersebut dengan tradisi Islam. Hal itu kemudian memicu timbulnya permasalahan-permasalahan baru yang dialami oleh umat Islam. $^{13}$ Ketika muncul beberapa permasalahan baru, sedangkan informasi yang dapat diakses dari teks-teks yang ada ternyata terbatas, maka ha ini lah yang kemudian memicu timbulnya perkembangan ijtihad. Beberapa kasus baru tersebut kemudian menimbulkan fatwa-fatwa dari para shahabat.

Pada mulanya, masih dimungkinkan terjadi kesepakatan antara beberapa orang shahabat dalam suatu permasalahan. Namun ketika kekuasaan Islam semakin bertambah luas, dan para shahabat semakin terpencar pada wilayah kekuasaan Islam yang saling berjauhan, maka yang terjadi kemudian ialah, tiaptiap shahabat melakukan ijtihad dengan kasar permasalahan yang mereka hadapi. Disinilah kemudian muncul dan berkembang pesat qaul shahabi.

12 Tarhib Ad Dusiri, Hujjiyyatu Qaul Ash Shahabiy 'inda as Salaf, (Madinah: Jami'ah Al Madinah), 23.

${ }^{13}$ Ahmad Kholiq, Melacak Sejarah Metodologi Ijtihad, (Bandung: Sahifa, 2009), 54 . 
$26 \mid$ Muchamad Coirun Nizar

Di antara beberapa qaul shahabi yang terkenal antara lain: 1. Qaul Aisyah r.a tentang usia kehamilan maksimal 2 tahun:

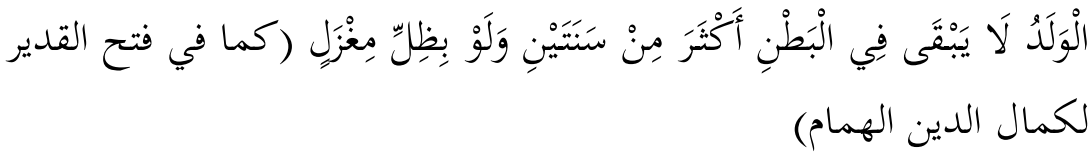

2. Qaul Anas yang diikuti Imam Abu Hanifah tentang rentang waktu minimal haid perempuan yaitu tiga hari.

3. Qaul Umar Ibn Khattab:

a) Perbuatan kejahatan terhadap mata hewan dikenai tanggungan seperempat harga hewan tersebut

b) Pembatalan pernikahan yang dilangsungkan pada masa iddah

c) Masa menunggu bagi wanita yang suaminya hilang selama empat tahun (masa kehamilan paling lama). ${ }^{14}$

\section{Ikhtilaf Ulama dalam Kehujjahan Qaul shahabi}

Sebagaimana telah disebutkan bahwa Ulama berbeda pendapat tentang kehujjahan qaul shahabi. Qaul shahabi merupakan rujukan hukum demi menyelesaikan peristiwaperistiwa hukum baru yang terjadi pasca meninggalnya Rasulullah yang tidak terdapat ketentuannya dalam Alquran dan Sunnah. ${ }^{15}$ Terdapat dua golongan Ulama dalam menyikapi qaul shahabi sebagai hujjah syar'iyyah, yaitu golongan yang setuju menjadikan qaul shahabi sebagai hujjah dan golongan yang menolaknya. Penjelasannya secara rinci ialah sebagai berikut:

\section{Ulama yang setuju}

Di antara Ulama yang setuju dengan qaul shahabi untuk menjadi hujjah ialah Imam Malik, Ar Razi, Hanafiyyah, Syafi'i (Qaul Qadim), Ahmad bin Hanbal (pendapat terkuat).

${ }^{14}$ Musthafa Said al Khin, Atsar al Ikhtilaf fi al qawa'id al Ushuliyyah $f i$ ikhtilaf al Fuqaha', (Beirut: Ar Risalah, 1998), 535-538.

${ }^{15}$ Abd.Rahman Dahlan, Ushul...., 225. 
Landasan dalam menjadikan qaul shahabi sebagai hujjah antara lain:

a) QS: An Nisa' : 110

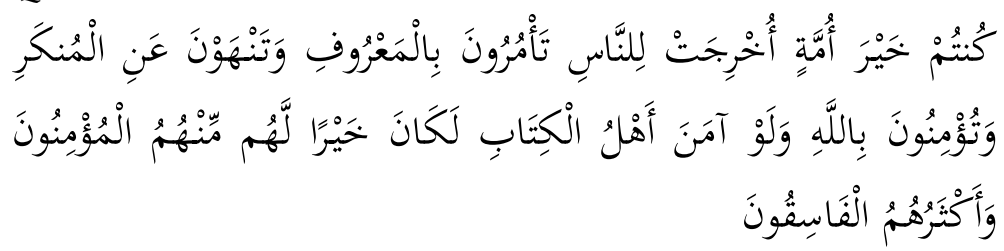

Artinya: "Kamu adalah umat yang terbaik yang dilahirkan untuk manusia, menyuruh kepada yang makruf, dan mencegah dari yang mungkar, dan beriman kepada Allah. Sekiranya Ahli Kitab beriman, tentulah itu lebih baik bagi mereka; di antara mereka ada yang beriman, dan kebanyakan mereka adalah orangorang yang fasik"

b) QS. At Taubah: 100

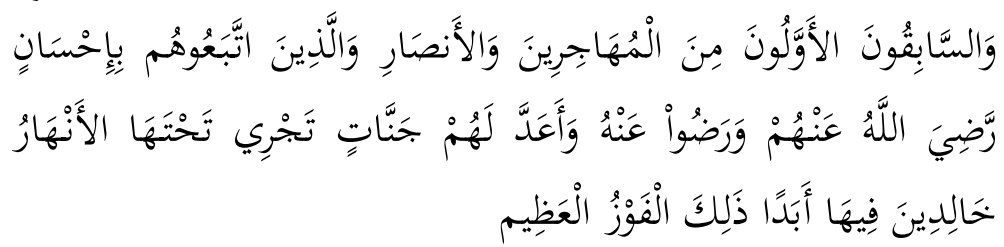

Artinya: " Dan orang-orang yang terdahulu lagi yang pertamatama (masuk Islam) di antara orang-orang muhajirin dan Anshar dan orang-orang yang mengikuti mereka dengan baik, Allah ridha kepada mereka dan mereka pun ridha kepada Allah. Allah menyediakan bagi mereka surga-surga yang mengalir di bawahnya sungai-sungai. Mereka kekal di dalamnya selamalamanya. Itulah kemenangan yang agung."

c) HR. Al Bukhari:

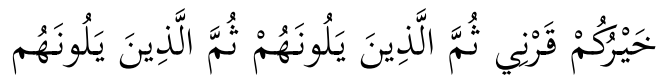

Artinya: "sebaik-baik kamu (adalah yang hidup pada) masaku, kemudian generasi berikutnya, kemudian generasi berikutnya" 16

${ }^{16}$ Al Bukhari, Al Jami' as Sahih, Juz 4, (Beirut: Dar Thauq an Najah, 1422 H.), 171. 
$28 \mid$ Muchamad Coirun Nizar

d) HR. Abu Daud, Tirmidzi dan Ibnu Majah:

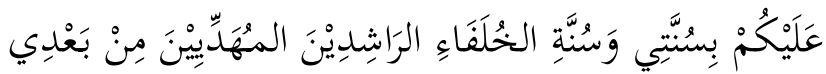

Artinya: "adalah kewajibanmu untuk mengikuti sunnahku dan sunnah khulafa al-Rasyidin yang datang sesudahku".

e) Hadis Ibnu Umar:

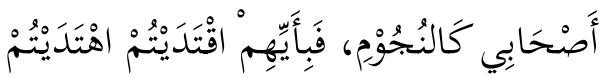

Artinya: "Sahabatku adalah bagaikan bintang, maka siapapun di antara mereka yang kalian jadikan panutan, maka kalian akan mendapatkan petunjuk."17

f) Ijma'

Keputusan pengangkatan Khalifah Utsman oleh Abdurrahman Ibn Auf dengan salah satu pertimbangannya yaitu mau mengikuti Khalifah sebelumnya yakni Abu Bakar dan Umar Ibn Khattab. ${ }^{18}$

g) Dalil Aqli (logika)

Di antara alasan logis yang menjadi dasar kehujjahan qaul shahabi antara lain:

1) Pendapat Shahabat dijadikan hujjah karena terdapat kemungkinan bahwa pendapat mereka berasal dari Rasulullah.

2) Kedekatan Shahabat dengan Rasulullah dalam waktu yang lama memberikan mereka pengalaman yang sangat luas untuk memahami ruh dari syariat dan tujuan-tujuan pensyariatan.

3) Mereka berguru langsung pada Rasululla sehingga diyakini pendapat mereka lebih mendekati kebenaran.

${ }^{17}$ Ibnu Hajar, Fath al Bari, Juz 4, (Beirut: Dar al Ma'rifah, 1389), 57.

18 Musthafa Said al Khin, Ushul Al Fikh Al Islami Tarihuhu wa Tathowwuruhu, (Beirut: Dar al kalam at Thayyib, 2000).

ulul albab: Jurnal Studi dan Penelitian Hukum Islam 
4) Mereka adalah generasi terbaik yang memiliki sifat 'adalah dan lebih jauh dari kemungkinan melahirkan pendapat syara' tanpa alasan. ${ }^{19}$

Terdapat suatu pendapat yang menyatakan bahwa suatu kaum menyetujui qaul shahabi menjadi hujjah hanya qaul Abu Bakar dan Umar Ibn Khattab saja. Sedangkan sebagian Ulama' Hanafiyyah berpendapat bahwa qaul shahabi menjadi hujjah hanya khusus pada shahabat ahli fatwa.

\section{Ulama yang menolak}

Golongan Ulama yang menolak qaul shahabi menjadi hujjah antara lain Asya'irah, Mu'tazilah, Syafi'i (Qaul Jadid), Syi'ah, Al Karkhi, Ulama Kontemporer Madzhab Maliki dan Hanafi, Ibnu Hazm. Pendapat mereka dalam menolak qaul shahabi berdasarkan sebagai berikut:

a) QS. Al Hasyr :2

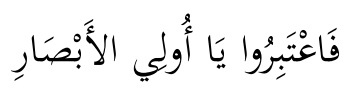

Artinya: "Maka ambillah kejadian itu untuk menjadi pelajaran wahai orang-orang yang memiliki pandangan."

b) Dalil Ijma'

Para Shahabat sendiri telah bersepakat bahwa bisa jadi di antara mereka terjadi perselisihan pendapat. Jika qaul shahabi menjadi hujjah, maka dapat dipastikan adanya kewajiban mengikuti bagi para shahabat lain. Akan tetapi, hal itu tidak terjadi. ${ }^{20}$

c) Dalil aqli (Logika)

Shahabat juga termasuk golongan mujtahid yang juga memiliki peluang salah atau lupa. Sama halnya dengan para tabi'in yang juga masuk golongan mujtahid. Oleh karena itu, Mujtahid generasi tabi'in dan sesudahnya tidak wajib mengikuti qaul shahabat.

d) Fakta Historis

${ }^{19}$ Abd.Rahman Dahlan, Ushul...., 225.

${ }^{20}$ Wahbah Az Zuhaili, Ushul al Fikh...., 854. 
$30 \mid$ Muchamad Coirun Nizar

Pengakuan beberapa Shahabat yang berbeda pendapat dengan pendapat Tabi'in menunjukkan bahwa qaul shahabat bukan hujjah. Salah satunya ialah ketika Anas bin Malik (golongan Shahabat) ditanya tentang suatu masalah. Beliau berkata: "Tanyakan permasalahan ini pada pemimpin kita, Al Hasan". Padahal Al Hasan dari golongan Tabi'in.

Al Ghazali termasuk seseorang yang meniadakan kehujjahan qaul shahabi secara mutlak. Beliau berpendapat bahwa para shahabat, siapapun itu, tidak ada jaminan bahwa mereka terbebas dari kesalahan sebagaimana keistimewaan Nabi. Bukan suatu rahasia lagi bahwa antar para sahabat kadang terjadi ikhtilaf. Terjadinya ikhtilaf di antara mereka merupakan dalil nyata bahwa pendapat mereka tidak dapat dijadikan hujjah. ${ }^{21}$

Musthafa Said al Khin dalam kitabnya Ushul Al Fikh Al Islami Tarihuhu wa Tathowwuruhu, menjelaskan secara mendetail tentang posisi qaul shahabi dalam menjadi hujjah syar'iyyah secara hierarki dalam sudut pandang masingmasing madzhab. Berikut sikap masing-masing madzhab terhadap qaul shahabi dalam kekuatannya sebagai hujjah syar'iyyah:

1. Madzhab Hanafi

Qaul shahabi dalam madzhab Hanafi menjadi hujjah ketiga setelah Alquran dan as sunnah di posisi pertama dan kedua. Menurut madzhab Hanafi, Qaul shahabi menjadi hujjah ketika menjangkau perkara-perkara yang yang tidak dapat dijangkau oleh qiyas. Dalam hal ini, mereka mendahulukan qaul shababi daripada qiyas. Sedangkan qaul shahabi yang menyangkut perkara-perkara yang dapat dijangkau oleh qiyas, mereka berselisih pendapat. Ada

${ }^{21}$ Al Ghazali, Al Mustashfa, (Beirut: Dar al Kitab al Ilmiyyah, 2010), 267.

ulul albab: Jurnal Studi dan Penelitian Hukum Islam 
yang tetap memprioritaskannya menjadi hujjah atas qiyas. Ada pula yang memandangnya bukan sebagai hujjah. ${ }^{22}$

2. Madzhab Maliki

Madzhab Maliki, meletakkan qaul shahabi sama seperti madzhab hanafi, yaitu menjadi hujjah syar'iyyah ketiga setelah Alquran dan as sunnah. Mereka secara mutlak lebih mengedepankan qaul shahabi daripada ijma' dan qiyas.

3. Madzhab Syafi'i

Madzhab Syafi'i secara institusi juga menjadikan qaul shahabi sebagai hujjah syar'iyyah. Akan tetapi, peletakannya secara jierarkis berada di bawah Alquran, sunnah, Ijma', Qiyas, dan Istishhab. Sedangkan sikap Imam Asy Syafi'i sendiri ialah, meski dalam qaul qadim mengakui qaul shahabi sebagai hujjah, akan tetapi dalam qaul jadid beliau hanya menerima qaul shahabi sebagai hujjah ketika dalam qaul shahabi tersebut mengandung unsur qiyas. ${ }^{23}$

4. Madzhab Hanbali

Sikap madzhab Hanbali terhadap qaul shahabi ialah sebagaimana sikap madzhab Hanafi dan Maliki yaitu menerima qaul shahabi sebagai hujjah ketiga setelah Alquran dan sunnah. Bahkan Imam Ahmad lebih mendahulukan qaul shahabi daripada hadis dalam tingkatan mursal atau dhaif. ${ }^{24}$

5. Madzhab Syiah

Golongan syiah sebenarnya menolak secara mutlak terhadap qaul shahabi dalam menjadi hujjah syar'iyyah. ${ }^{25}$ Akan tetapi bagi golongan syiah Zaidiyyah dan Imamiyyah, mereka menganggap qaul shahabat yang

22 Asmawi, Perbandingan Ushul Fikh, (Jakarta: Amzah, 2011), 168.

${ }^{23}$ Wahbah Az Zuhaili, Ushul al Fikh... , 853.

${ }^{24}$ Ibid., 853.

${ }^{25}$ Ibid., 851. 
$32 \mid$ Muchamad Coirun Nizar

termasuk dalam ahl bait merupakan hujjah yang wajib diikuti. ${ }^{26}$

6. Madzhab Dzahiri

Sikap madzhab adz Dzahiri terhadap qaul shahabi ialah menolak secara mutlak. Mereka berpendapat bahwa tidak boleh bertaqlid kepada seseorang, termasuk shahabat.

7. Mu'tazilah

Mu'tazilah bersikap sama dengan Adz Dzahiri yaitu menolak qaul shahabi secara mutlak.

Zakariya Al Anshari menyebutkan tentang beberapa permasalahan yang berkaitan dengan kehujjahan qaul shahabi salah satunya ialah dapatkah qaul shahabi yang keluar dari salah seorang sahabat menjadi hujjah bagi sahabat lain. Dalam hal ini, Ulama' sepakat mengingkari kehujjahan qaul shahabi bagi sahabat lain. ${ }^{27}$ Sedangkan ketika qaul shahabi dijadikan hujjah bagi umat setelah masa sahabat, maka Ulama' berbeda pendapat mengenai hal ini. Perbedaan pendapat Ulama mengenai kehujjahan qaul shahabi bagi selain Sahabat antara lain :

1. Qaul Shahabi bukan merupakan hujjah syar'iyyah bagi siapapun dari kalangan mujtahid baik dari kalangan tabi'in maupun setelahnya. Pendapat ini merupakan qaul ashah ${ }^{28}$.

2. Qaul Shahabi merupakan hujjah syar'iyyah bagi selain sahabat dan memiliki derajat di atas qiyas.

3. Qaul Shahabi merupakan hujjah syar'iyyah bagi selain sahabat yang derajatnya di bawah qiyas.

${ }^{26}$ Dedi Ismatullah, Sejarah Sosial Hukum Islam, (Bandung: Pustaka Setia, 2011), 210.

27 Zakariya Al Anshari, Ghayah Al Wushul Syarh Lubb al Ushul, (Kairo, Dar al Kutub al Arabiyyah, 1306 H.), 147.

${ }^{28}$ Alasan dari pendapat ini ialah bahwa perkataan mujtahid secara mandiri meskipun dari kalangan sahabat, tidak dapat menjadi hujjah bagi mujtahid lain.

ulul albab: Jurnal Studi dan Penelitian Hukum Islam 
Qaul Shahabi dan Aplikasinya ... $\mid 33$

4. Qaul Shahabi menjadi hujjah bagi generasi tabi'in dan setelahnya manakala qaul tersebut telah tersebar dan tidak mendapat pertentangan dengan pendapat lain. ${ }^{29}$

5. Qaul Shahabi dapat menjadi hujjah bagi selain sahabat ketika menyalahi qiyas.

6. Qaul Shahabi yang dapat menjadi hujjah bagi selain sahabat hanya qaul Abu Bakar Ash Shidiq dengan Umar bin Khattab saja. ${ }^{30}$

Dari ikhtilaf yang terjadi, Wahbah Zuhaili mengambil suatu tarjih dengan menyatakan bahwa qaul shahabi yang merupakan pendapat perorangan bukan merupakan hujjah syar'iyyah yang berdiri sendiri. Sebab memiliki peluang benar dan salah. Qaul shahabi tersebut dapat menjadi hujjah yang diikuti ketika memiliki sandaran dalam bentuk nash baik Alquran maupun sunnah. ${ }^{31}$

\section{Aplikasi Qaul Shahabi dalam Fiqh Kontemporer}

Sudah menjadi suatu keniscayaan bahwa suatu ikhtilaf yang terjadi akan menimbulkan pengaruh terhadap beberapa permasalahan. Berikut beberapa permasalahan yang terkena dampak ikhtilaf Ulama dalam qaul shahabi:

1. Jual Beli Kredit

Jual beli 'inah merupakan praktik jual beli seperti ketika si A menjual barang kepada si B dengan harga tertentu dan untuk jangka waktu tertentu (secara tempo). Kemudian si A membeli kembali barang tersebut dengan harga lebih

${ }^{29}$ Pendapat ini disanggah bahwa ketika terjadi semacam itu, maka kehujjahan pendapat tersebut bukan sebagai qaul shahabi melainkan sebagai ijma' sukuti. Artinya, antara pendapat yang dikeluarkan oleh sahabat dengan yang lain, memiliki kapasitas yang sama sebagai hujjah syar'iyyah ketika tidak ditentang oleh pendapat lain.

30 Zakariya Al Anshari, Ghayah Al Wushul... 147.

${ }^{31}$ Wahbah Az Zuhaili, Ushul al Fikh..., 857. 
$34 \mid$ Muchamad Coirun Nizar

rendah secara tunai. Artinya, jual beli 'inah sama dengan jual beli kredit dengan tambahan harga.

Menurut Ulama Syafi'iyyah, praktik jual beli dalam bentuk sebagaimana disebutkan diperbolehkan dengan berdasarkan qiyas. Sedangkan Ulama Malikiyyah, Hanafiyyah dan Hanabilah memandang bahwa praktik jual beli tersebut tidak sah dan haram. Mereka menggunakan dasar qaul shahabi yakni qaul Aisyah yang memberi tanggapan buruk terhadap praktik jual beli yang dilakukan oleh keluarga Zaid bin Arqam. Praktik jual beli tersebut dengan cara sebagaimana digambarkan sebelumnya. ${ }^{32}$

2. Waktu maksimal kehamilan.

Ulama berbeda pendapat tentang rentang waktu maksimal bagi wanita hamil. Ulama Hanafiyyah berpendapat bahwa waktu kehamilan maksimal bagi wanita ialah dua tahun berdasarkan qaul shahabi yakni qaul Aisyah yang menyatakan:

$$
\text { الولد لا يبقى في البطن أكثر من سنتين ولو فلكة مغزل }
$$

Artinya: "Seorang anak tidak tinggal dalam kandungan ibunya lebih dari dua tahun meskipun berupa sebulatan pintalan benang."

Sedangkan menurut Ulama Malikiyyah, Syafiiyyah dan Hanabilah, waktu maksimal kehamilan ialah empat tahun. Hal ini berdasarkan pada fakta kehidupan yaitu adanya sejumlah bayi yang hidup dalam kandungan ibunya selama empat tahun. ${ }^{33}$

3. Ganti rugi atas pencederaan hewan ternak

Ulama Hanafiyyah berpendapat bahwa ketika hewan ternak seperti unta, sapi dan kuda dicederai, maka kadar ganti ruginya ialah seperempat dari harga standar hewan

${ }^{32}$ Musthafa Said al Khin, Atsar al Ikhtilaf..., 534-535.

${ }^{33}$ Ibid., 534-535.

ulul albab: Jurnal Studi dan Penelitian Hukum Islam 
Qaul Shahabi dan Aplikasinya ... $\mid 35$

tersebut. ${ }^{34}$ Pendapat tersebut berdasarkan qaul Umar ibn Khattab dalam suratnya kepada Syuraih yang intinya bahwa ganti rugi hewan yang dicederai matanya ialah seperempat dari harga standar hewan tersebut.

Sedangkan menurut Ulama Malikiyyah, Syafiiyyah dan Hanabilah, kadar ganti ruginya ialah senilai dengan harga yang terkurangi dari harga standar hewan tersebut. Berdasarkan dengan qiyas, yakni qiyas kepada kasus perbuatan melawan hukum terhadap harta kekayaan orang lain. ${ }^{35}$

4. Masa minimal menstruasi

Ulama Hanafiyyah berpendapat bahwa kadar waktu tersingkat menstruasi perempuan ialah $3 \times 24$ jam atau tiga hari. Dasar pendapat mereka ialah qaul Anas bin Malik yang menyatakan bahwa masa menstruasi kaum perempuan ialah tiga, empat, lima, enam, tujuh, delapan, sembilan, atau sepuluh hari. Sedangkan Ulama Malikiyyah, Syafiiyyah dan Hanabilah berpendapat bahwa waktu tersingkat menstruasi ialah 1x24 jam atau sehari semalam. Mereka berargumen bahwa sesuatu yang tidak disinggung oleh nash ketentuannya, maka dikembalikan kepada urf. Sedangkan berdasarkan urf, terdapat wanita yang waktu menstruasinya hanya $1 \times 24$ jam saja. ${ }^{36}$

\section{Qaul Shahabi Sebagai Ijtihad Tekstual}

Qaul shahabi merupakan pendapat satu orang shahabah yang kemudian menyebar di kalangan shahabah lainnya, tanpa diketahui seorang shahabat pun yang menentang. Qaul shahabi menjadi obyek ikhtilaf di kalangan Ulama ketika qaul shahabi

34 Tidak termasuk hewan kambing dan domba. Sebab kedua hewan tersebut jika dicederai, maka kadar ganti ruginya senilai dengan harga hewan yang terkurangi akibat cedera tersebut. Dan ini tidak ada ikhtilaf.

${ }^{35}$ Musthafa Said al Khin, Atsar al Ikhtilaf..., 534-535.

${ }^{36}$ Ibid., 534-535. 
36 |Muchamad Coirun Nizar

menjadi hujjah bagi generasi Tabi'in dan sesudahnya. Dalam sejarahnya, ekspansi wilayah Islam ke berbagai daerah menjadi faktor yang ikut melatarbelakangi timbulnya permasalahanpermasalahan baru yang kemudian mengharuskan para shahabat untuk mengeluarka fatwa hukum.

Jika melihat klasifikasi metode istinbath atau dalil hukum yng terdapat dalam ilmu ushul fiqh, qaul shahabi termasuk dalam kategori dalil yang berorientasikan pada teks, bukan $r a^{\prime} y u$. Jika seseorang berpegangan pada qaul shahabi, artinya dia mengikuti pendapat hasil ijtihad dari salah seorang shahabat Nabi secara tekstual. Berbeda dengan penggunaan dalil seperti qiyas atau mashlahah yang cenderung berorientasikan pada $r a^{\prime} y u$. Jenis dalil hukum lainnya yang berorientasikan pada teks antara lain Alquran, Sunnah dan Ijma'.

Kehujjahan qaul shahabi diperselisihkan oleh kalangan Ulama. Di antara Ulama yang menerima qaul shahabi sebagai hujjah syariyyah antara lain Imam Malik, Ar Razi, Hanafiyyah, Syafi'i (Qaul Qadim), Ahmad bin Hanbal (pendapat terkuat). Sedangkan golongan yang menolak qaul shahabi menjadi hujjah antara lain Asya'irah, Mu'tazilah, Syafi'i (Qaul Jadid), Syi'ah, Al Karkhi, Ulama Kontemporer Madzhab Maliki dan Hanafi, Ibnu Hazm. Dari ikhtilaf tersebut, kemudian menimbulkan tarjih dari Wahbah az Zuhaili dengan berpendapat bahwa qaul shahabi yang merupakan pendapat perorangan bukan merupakan hujjah syar'iyyah yang berdiri sendiri. Sebab memiliki peluang benar dan salah. Qaul shahabi tersebut dapat menjadi hujjah yang diikuti ketika memiliki sandaran dalam bentuk nash baik Alquran maupun sunnah. Ikhtilaf Ulama dalam qaul shahabi memberikan pengaruh terhadap beberapa permasalahan antara lain masalah jual beli kredit, waktu maksimal kehamilan, ganti rugi pencideraan hewan dan waktu minimal haid.

Dalam rangka mencermati terhadap aplikasi qaul shahabi terhadap permasalahan fiqh baik klasik maupun kontemporer, nampaknya dapat diketahui bahwa penggunaan qaul shahabi 
dalam permasalahan tertentu, menurut Jumhur Ulama dinaskh ketentuannya oleh metode lain seperti qiyas. Hanya pada ketentuan jual beli sistem kredit saja yang berbeda, dikarenakan Jumhur lebih memilih mendasarkan pendapatnya pada qaul shahabi. Artinya, jika kembali merujuk pada pernyataan Zakariya Al Anshari dalam kitab Ghayah al Wushul, qaul shahabi setidaknya ketika dikategorikan sebagai hujjah syar'iyyah, namun derajatnya ada di bawah qiyas. Konsekuensinya, ketika terjadi ta'arudh al adillah, maka dimenangkan ketentuan melalui metode qiyas. Meski begitu, penggunaan qaul shahabi sebagai hujjah yang derajatnya di bawah qiyas merupakan pendapat yang bertentangan dengan qaul al ashah. Karena menurut qaul al ashah, qaul shahabi bukanlah termasuk hujjah syar'iyyah. Demikian, $W a$ Allahu A'lam.

\section{Daftar Pustaka}

Al-Quran al-Karim

Al Bukhari, Al Jami' as Sahih, Juz 4, (Beirut: Dar Thauq an Najah, 1422 H.)

Ibnu Hajar, Fath al Bari, Juz 4, (Beirut: Dar al Ma'rifah, 1389)

Wahbah Az Zuhaili, Ushul al Fikh al Islami, (Beirut: Dar al Fikr, 1986)

Abd.Rahman Dahlan, Ushul Figh, (Jakarta: Amzah,2010)

Satria Effendi,M.Zein, Ushul Figh,(Jakarta;Kencana,2009)

Tarhib Ad Dusiri, Hujjiyyatu Qaul Ash Shahabiy 'inda as Salaf, (Madinah: Jami'ah Al Madinah)

Musthafa Said al Khin, Atsar al Ikhtilaf fi al qawa'id al Ushuliyyah fi ikhtilaf al Fuqaha', (Beirut: Ar Risalah, 1998) Ushul Al Fikh Al Islami Tarihuhu wa

Tathowwuruhu, (Beirut: Dar al kalam at Thayyib, 2000)

Zakariya Al Anshari, Ghayah Al Wushul Syarh Lubb al Ushul, (Kairo, Dar al Kutub al Arabiyyah, 1306 H.)

Al Ghazali, Al Mustashfa, (Beirut: Dar al Kitab al Ilmiyyah, 2010) Asmawi, Perbandingan Ushul Fikh, (Jakarta: Amzah, 2011) 
$38 \mid$ Muchamad Coirun Nizar

Ahmad Warson Munawwir, Kamus Al Munawwir, (Surabaya: Pustaka Progressif, 1997)

Jaenal Aripin, Kamus Ushul Fikh, (Jakarta: Kencana, 2012)

Ahmad Kholiq, Melacak Sejarah Metodologi Ijtihad, (Bandung: Sahifa, 2009)

Dedi Ismatullah, Sejarah Sosial Hukum Islam, (Bandung: Pustaka Setia, 2011) 